\title{
Interface between psychoanalysis and speech language and hearing sciences: a literature review
}

\author{
Interface entre a psicanálise e a fonoaudiologia: uma revisão da literatura
}

\author{
Edinalva Neves Nascimento(1) \\ Dayse Mayara Oliveira Ferreira ${ }^{(1)}$ \\ Flávia Rodrigues dos Santos ${ }^{(1)}$ \\ Nayra Neri da Silva ${ }^{(1)}$ \\ Sabrina Alves de Oliveira ${ }^{(1)}$ \\ Joyra da Silva Carrer ${ }^{(1)}$ \\ Letícia Alvieri Riato(1) \\ Marina Mendes Gozzer ${ }^{(1)}$
}

(1) Departamento de Fonoaudiologia. Universidade Estadual Paulista Júlio de Mesquita Filho, Marília, São Paulo, Brasil.

Conflict of interest: non-existent

Received on: March 31, 2017 Accepted on: June 07, 2017

\section{Mailing address:}

Edinalva Neves Nascimento

Rua Santa Helena, 1967 casa 27

Jardim Estoril

Marília - São Paulo - SP

CEP: $17514-410$

E-mail: ediquata@gmail.com

\section{ABSTRACT}

The aim of this study was to verify the Brazilian and international scientific productions by correlating Speech Language and Hearing Sciences and Psychoanalysis. A literature review was performed using the databases BVS, Scielo, Scopus and PubMed. The used descriptors were "Fonoaudiologia", "Psicanálise", "Comunicação", "Speech Therapy", "Psychoanalysis" and "Communication", identifying 65 full articles between the years 1980 and 2015. The analysis was performed using a "Protocol for article classification". It was verified that Original Articles are the most published type, SCOPUS and BVS being the most common databases. There is a predominance of articles in the Portuguese language, followed by English, French and German. Several specialties of Speech Language and Hearing Sciences presented interface with Psychoanalysis, especially Language and Neuropsychology. The studies were published mainly in Psychology journals, also found in the area of audiology and interdisciplinary area. This review showed the psychoanalytic interference in speech language and hearing clinic, highlighting the need for further studies correlating both areas that may contribute to the work of these professionals and, consequently, enable an improvement in the quality of life of psychic subjects.

Keywords: Speech, Language and Hearing Sciences; Psychoanalysis; Communication

\section{RESUMO}

0 objetivo deste estudo foi verificar na literatura brasileira e internacional produções científicas correlacionando a Fonoaudiologia e a Psicanálise. Foi realizada revisão de literatura utilizando as bases de dados BVS, Scielo, Scopus e PubMed. Foram utilizados os descritores "Fonoaudiologia", "Psicanálise", "Comunicação", "Speech Therapy", "Psychoanalysis" e "Communication" e identificados 65 artigos completos entre os anos de 1980 a 2015. A análise foi realizada por meio de um "Protocolo de Classificação de Artigos". Foi possível verificar que o tipo de trabalho mais publicado é o Artigo Original. Observou-se que SCOPUS e BVS foram as bases de dados mais comuns. Há um predomínio de artigos no idioma português, seguido por inglês, francês e alemão. Várias especialidades da Fonoaudiologia apresentaram interface com a psicanálise, especialmente, Linguagem e Neuropsicologia. Os trabalhos foram publicados principalmente em periódicos da Psicologia, sendo encontrados também na área da Fonoaudiologia e da Interdisciplinar. Este trabalho de revisão evidenciou a interferência psicanalítica na clínica fonoaudiológica, verificando a necessidade de mais estudos relacionando ambas as áreas que possam contribuir para a atuação desses profissionais e, consequentemente, possibilitar uma melhora na qualidade de vida do sujeito psíquico.

Descritores: Fonoaudiologia; Psicanálise; Comunicação 


\section{INTRODUCTION}

According to the psychoanalytic theory, the psychic apparatus is structured in three instances, namely id, superego and ego. Id is the most primitive one, related to the instinct, being led by the principle of pleasure in the search for satisfaction. Superego is the most improved instance of psyche, which, being ruled by the principle of reality, follows the social and cultural rules, determining what pulses must be satisfied, postponed, or not quenched by the ego. Ego is the conscience, the "I" that mediates between id and superego, responsible for decision-making. The pulses of id which are not carried out by ego are repressed by superego and stored in the unconscious, interfering in people's lives through dreams, Freudian slips, and symptoms ${ }^{1,2}$.

The unconscious is above all formed by repressed contents which were not satisfied by conscience. These contents try to return to the plan of conscience, but it is only possible if they go through a process of transformation by condensation or displacement. Condensation is a set of repressed pulses which are organized in associative chains and escape mainly through dreams. In displacement, this chain is detached and passes to another one of less intensity, and can be observed especially in psychoneurotic symptoms, there being a transfer from a symptom to another ${ }^{3}$.

The interface between language and hearing sciences and psychology was initially observed in the bibliographic search made between 2004 and 2014 in electronic journals of language and hearing sciences. The study demonstrated a close relation between the two areas ${ }^{4}$. However, the research mentioned did not indicate which theoretical school subsidized the studies that were analyzed, that is to say, if they were supported by a behavioral, innatist, constructivist, socio-interactionist, or a psychoanalytic approach.

The psychoanalytic discourse about human functioning has contributed in the exercise of clinical speech therapy, as it was demonstrated in a research conducted with the courses of language and hearing sciences in the country. The inquiries made with the professors about this theory showed that the approach is used in the processes of intervention in speech, fluency, voice, orofacial motricity and hearing ${ }^{5}$.

Psychoanalysis has as its object of study the unconscious and it defends that contents that are repressed and stored in this "black box" can interfere in human communication and result in psychopathologic symptoms. Regarding the unconscious, the analytic theory can contribute with the comprehension of the emotional dimensions involved in the origin of these signs $^{6}$. However, one can ask: are there in national and international literature works which relate psychoanalysis to language and hearing sciences? When was that literature produced? In what databases were they made available? What specialties of language and hearing sciences receive more interference by the analytic view?

Thus, the aim of this study was to make a review of national and international literature, correlating psychoanalysis and language and hearing sciences.

\section{METHODS}

According to the aims that were defined, this study is characterized as both exploratoryand bibliographic, considering the technical procedures that were used in the collection of data. The follow-up period of the research defined it as longitudinal and the temporal directionality qualified it as a retrospective one ${ }^{7,8}$.

A systematic review of the literature about language and hearing sciences was done, correlating language and hearing sciences/communication and psychoanalysis. The collecting happened in national databases "Biblioteca Virtual em Saúde (BVS)" and "Scientific Electronic Library (SCIELO)" and international databases "Scopus" and "Pubmed". The descriptors used to find the articles in Portuguese were "Fonoaudiologia", "Psicanálise" and "Comunicação", and in English, "Speech Therapy", "Psychoanalysis" and "Communication". The search was made associating the descriptors the following way: Fonoaudiologia $X$ Psicanálise; Comunicação X Psicanálise; Speech Therapy $X$ Psychoanalysis and Communication $X$ Psychoanalysis. Initially, 545 articles were found in national databases and 4,167 in international ones.

Original articles of research, bibliographic review, case studies, chapters of books and others which were available in their whole were included in this study. Whenever it was impossible to access an article for free, the Virtual Private Network (VPN) was used. It is available toundergraduate students of language and hearing sciences of the public university of the state of São Paulo.

The first analysis of the article was performed through the inspection of the title and abstract. Those which were not in accordance with the theme were eliminated, resulting in a final sample of 65 works.

Then, the detailed analysis of the works was done using a "Protocol of Classification of Articles" adapted from the study of Nascimento et al. (2016) ${ }^{4}$ and Vasconcelos, Pessoa and Farias (2008) $)^{9}$, as shown in Figure 1. 
PROTOCOL OF CLASSIFICATION OF STUDIES

\begin{tabular}{|c|c|c|}
\hline \multicolumn{3}{|c|}{ Title of the Study: } \\
\hline \multicolumn{3}{|l|}{ Journal: } \\
\hline \multicolumn{3}{|l|}{ Year: } \\
\hline \multicolumn{3}{|l|}{ Language: } \\
\hline \multicolumn{3}{|l|}{ Database: } \\
\hline \multirow{11}{*}{ Area: } & Audiology & \\
\hline & Dysphagia & \\
\hline & Gerontology & \\
\hline & Educational Speech Therapy & \\
\hline & Neurofunctional Speech Therapy & \\
\hline & Labor Speech Therapy & \\
\hline & \begin{tabular}{|l|} 
Neuropsychology \\
\end{tabular} & \\
\hline & Language & \\
\hline & Orofacial Motricity & \\
\hline & Voice & \\
\hline & Public Health & \\
\hline \multirow{4}{*}{ Type of Study: } & Original Article & \\
\hline & Review Article & \\
\hline & Case Study & \\
\hline & Other: & \\
\hline \multicolumn{3}{|c|}{$\begin{array}{l}\text { Analysis of the study (to consider the participant subjects, age, place of the study, language and hearing alterations, psychoanalytic } \\
\text { interference) }\end{array}$} \\
\hline
\end{tabular}

Figure 1. Protocol of classification of studies

The systematic analysis of the identified works was done by four pairs of researchers who were trained in a sixty-hour Curricular Discipline, called "Constitution of the Psychic and Linguistic Subject", besides periodic meetings with the professor responsible for the discipline. The first categorization was done individually by the judges. Then, each pair of judges defined the classifications in a consensual way. If there was not a consensus, a third judge was activated.

In order to identify the area of knowledge of the works, the journals were accessed and the mission of each journal was checked. This classification was done by pairs of researchers.

In face of all the information identified in the literature, a scheme was structured to make it possible to synthesize the constitution of the psychic subject and the linguistic subject, as well as the interface with the language and hearing symptoms.

\section{RESULTS}

Sixty five articles were found, correlating speech therapy/communication and psychoanalysis between 1980 and 2015. Figure 2 presents a progression in the number of articles published between 1980 and 2003, followed by a decrease in 2001, 2004 and 2005, returning to a progressive increase until 2008. A peak of the production is noticed in 2012 and, from then on, the number of publication of articles started to decrease again.

Original Articles prevailed as the type of article published. SCOPUS and BVS were the most evident databases. Most of the articles were published in Portuguese.

Table 2 shows the specialties of language and hearing sciences which present an interface with psychoanalysis, language and neuropsychology, predominating, respectively. 


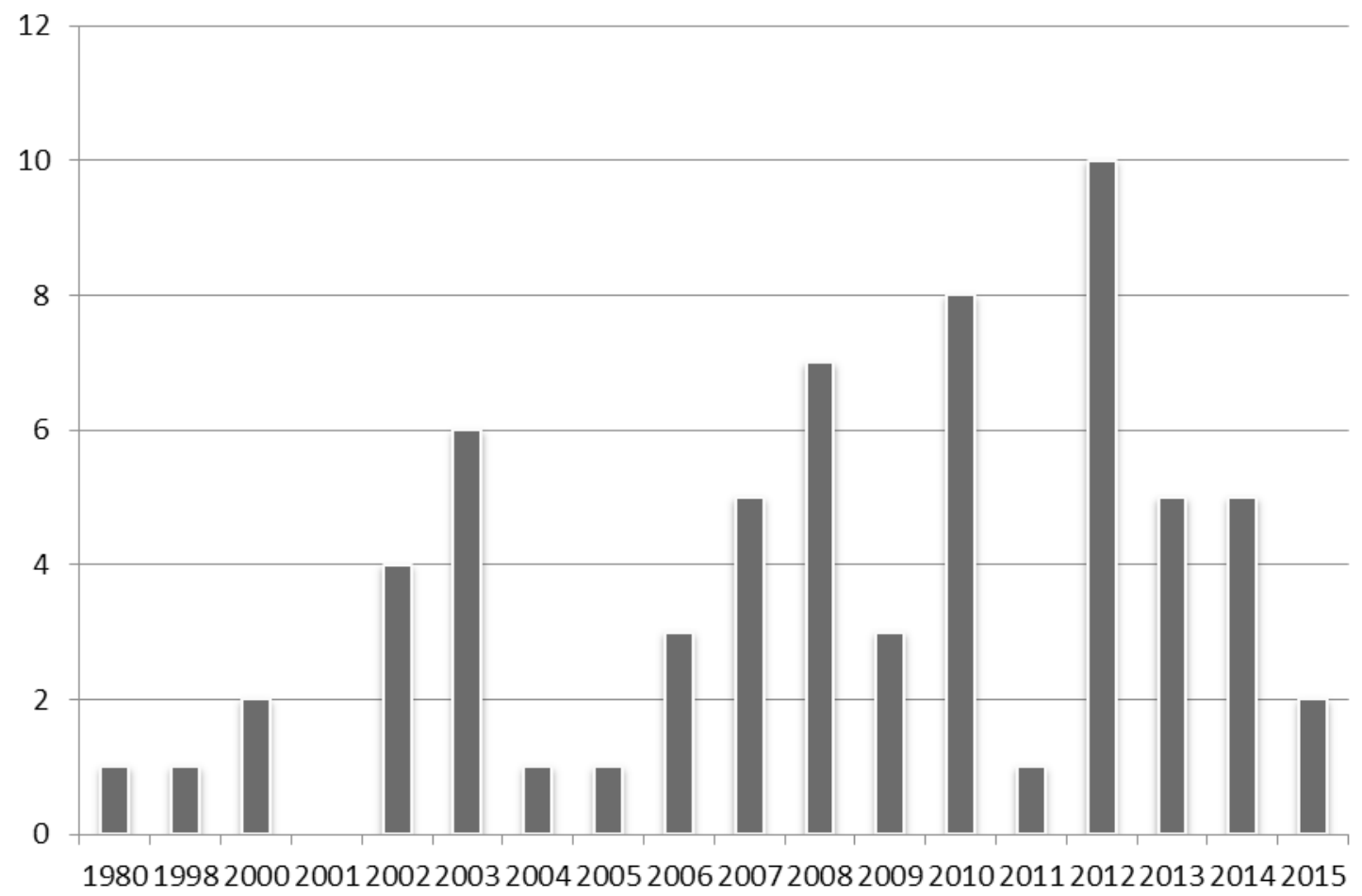

Figure 2. Distribution of the studies published each year

Table 1. Classification of the studies according to the type, database and language

\begin{tabular}{ccc}
\hline Type of work & Number of articles according to the type & $\%$ \\
\hline Original Article & 46 & 70.76 \\
Review Article & 9 & 13.84 \\
Case Study & 9 & 13.84 \\
Chapter & 1 & 1.53 \\
\hline Database & Number of articles per database \\
\hline SCOPUS & 18 & 27.69 \\
BVS & 18 & 27.69 \\
PUBMED & 16 & 24.61 \\
SCIELO & 14 & 21.53 \\
Another & 7 & 10.76 \\
\hline Language & Number of journals per language \\
\hline Portuguese & 36 & 55.38 \\
English & 27 & 41.53 \\
French & 1 & 1.53 \\
German & 1 & 1.53 \\
\hline
\end{tabular}


Table 2. Specialties of Speech Therapy in interface with Psychoanalysis.

\begin{tabular}{ccc}
\hline Specialties of Speech Therapy & Number of articles & $\%$ \\
\hline Language & 42 & 64.61 \\
Neuropsychology & 21 & 32.30 \\
Public Health & 4 & 6.15 \\
Voice & 2 & 3.07 \\
Audiology & 1 & 1.53 \\
Neurofunctional Speech Therapy & 1 & 1.53 \\
Orofacial Motricity & 1 & 1.53 \\
Fluency & 1 & 1.53 \\
\hline
\end{tabular}

Regarding the journals where the works were published, it is possible to notice that the area of psychology is predominantly the one that most publishes articles relating language and hearing sciences to psychoanalysis, followed by language and hearing sciences.
The national and international literature showed that the constitution of the psychic subject can interfere in the constitution of the linguistic subject through condensation and displacement, as shown in Figure 4.

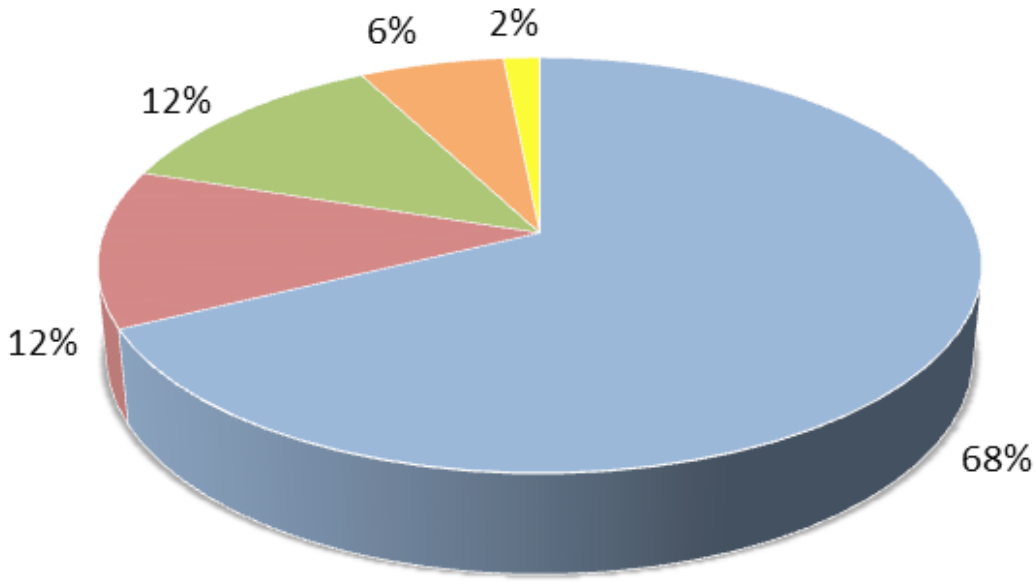

- Psychology

- Language and Hearing Sciences

- Interdisciplinary

Medical Science

Public Health

Figure 3. Area of knowledge where the studies were published
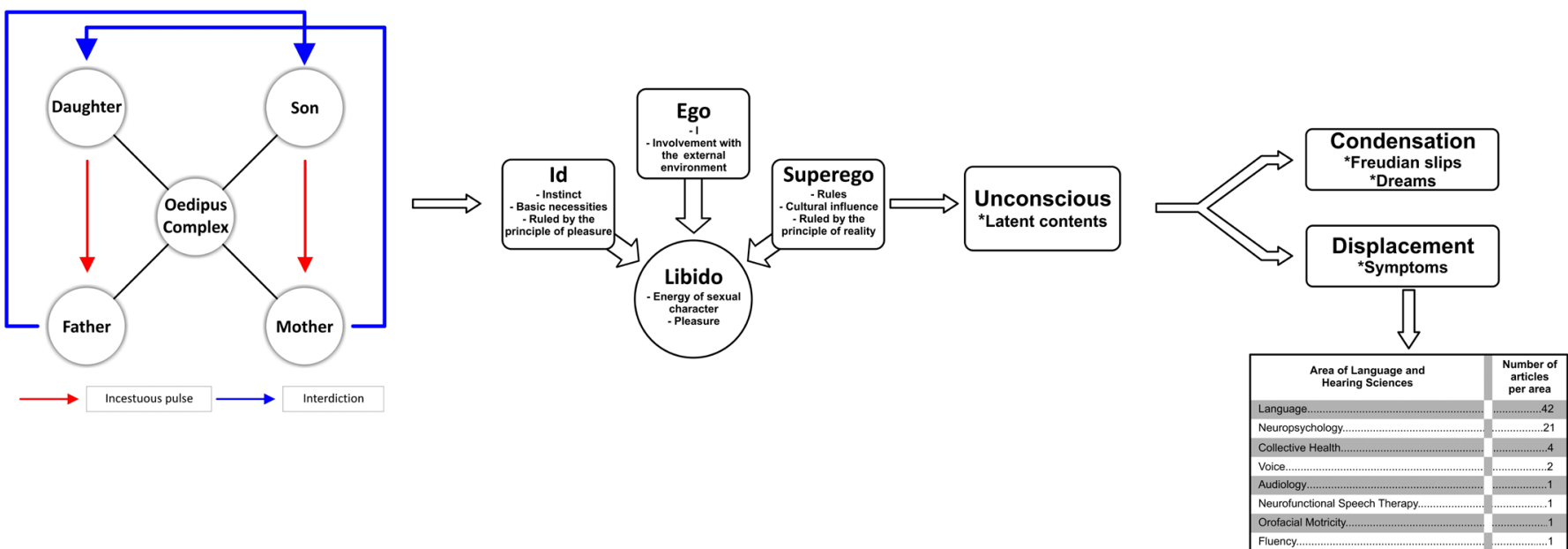

Figure 4. Layout of the psycholinguistic subject 
This study demonstrated that there are national and international scientific productions that correlate speech therapy and psychoanalysis. The results were similar to those in the study by Nascimento et al. $(2016)^{4}$ regarding the year of publication, database and speech therapy specialties.

The analysis of the scientific productions allowed us to observe that language continues to be the speech therapy specialty that is the most affected by psychopathologies. Language is the first form of manifestation of children's ${ }^{10}$ psyche and it reveals the culture, tradition and customs through the history constituted by human experience ${ }^{11}$.

By analyzing language under the view of psychoanalysis it is probable to identify intrapsychic and interpersonal abilities ${ }^{12}$. Psychoanalysis establishes a clinical field which recognizes the subject of unconscious constituted in and by language ${ }^{13}$. In the therapeutic space it is possible to interpret the communication established between therapist and patient ${ }^{14}$ and investigate the importance of the communication done by the other ${ }^{15}$.

The speech therapy clinic is a privileged space that makes it possible to analyze and interpret language as a symbolic instance of subjective aspects, that is to say, it is a field that allows identifying the interference of latent contents of unconscious in human communication ${ }^{16}$.

The language and hearing sciences and psychoanalysis are crossed by common questions that evidence an interface ${ }^{17}$, showing that the unconscious interferes in human communication and can help to understand emotional dimensions ${ }^{6}$. Thus, we must have a refined comprehension of the emotional aspect involved in the communicative interchange ${ }^{18}$.

The unconscious contents may appear in communication in different aspects, whether in the tone of the voice, in rhythm, in prosody, or even in the structure of speech ${ }^{19}$. The knowledge of psychoanalysis allows changing the relationship of the subject with his own unconscious psychic processes ${ }^{20}$ and thus identifying the origin of the symptoms and the strategies of intervention.

The analysis of the repressed contents in the unconscious can frequently redefine the therapeutic process $^{21}$, including language and hearing. Thus, the words must be evaluated, listening beyond the content, analyzing the sound and the meaning of what was said $^{22}$. For instance, the Lacanian psychoanalytic theory allows linking the communicative behavior and offers a set of symbolic coordinate ${ }^{23}$ which may be escaping from the unconscious.

In the interface between psychoanalysis and speech therapy it is possible to process the experiences and restore imaginative spaces which transmit contents that are not in conscience ${ }^{24}$. The analysis of silence is also important in the therapeutic work, because it allows the emergence of the transitional space through non verbal communication ${ }^{25}$. The conversation and analysis seem to be promising to the discovering of properties of the unconscious processes ${ }^{26}$, favoring a linguistic hearing which is more comprehensive and qualified ${ }^{27}$.

The national and international literature which was identified in this study showed some cases of speech therapy that presented interface with the psychoanaIytic theory. The analysis of a psychotic patient showed that the records of language helped in the building of a mental space $^{28}$. In another psychotic patient, there were some interruptions in speech, confuse discourse and incomplete sentences, associated to the delirious psychotic picture of persecution ${ }^{29}$.

A research with schizophrenic patients showed that they could not distinguish the mind from the world, establishing delusions. The common distinctions between words, things, state of body and actions are absent, creating words and sentences that are not symbolic $^{30}$.

In the interaction with a severe 20-year-old autistic, verbal communication was tried by the therapist, but the young man was resistant and with out of context laughs of escape. In one of the sessions the young man exposed about his father's death, and from then on started to establish a connection with the therapist and to have a verbal communication ${ }^{31}$. In this case, the death of his father could be something latent, pressing the subject's ego, contributing to the origin of language and hearing alterations.

Psychoanalysis also offers rich opportunities for the early treatment of the autism spectrum disorder, especially those that are out of the oedipal contact ${ }^{32}$. In a study carried out with three autistic children, between 2 and 4 years old, loose and out of context sentences, echolalic speech, jargons, stereotypies of hands, gesture communication, unintelligible speech and words without meaning were observed. Interviews with their parents were carried out, and they were interpreted based on a psychoanalytic analysis. The intervention allowed changes of feelings in the couple and in the behavior of the parents towards the children, having positive effects concerning the language disorders ${ }^{33}$. 
During a speech therapy attendance to three siblings, a delay in the development of language was identified in one of the children. Subsequently, the other sibling started presenting the same characteristics. The same happened to the third one, however with changes in speech and interposing of language. With the psychoanalytic approach it was possible to realize that the parents unconsciously used to make a comparison between the children, creating a competition and conflict between them, causing language and hearing alterations ${ }^{34}$.

A study carried out with eighteen relatives responsible for children with phonological disorders, sent to the Center of Language and Speech Study (CELF) of the Service of Speech Therapy Attendance (SAF) of the Federal University of Santa Maria (UFSM) allowed observing possible interventions in the language and hearing therapy. It was possible to identify that knowledge about the psychoanalytic theory improves the therapeutic performance ${ }^{35}$.

The speech therapeutic process, when it is supported by the psychoanalytic theory, offers subsidies that the professional may carry out intervention even in written production ${ }^{36}$, as well as in other areas of the different specialties of language and hearing sciences like, for instance, the voice.

In relation to the voice disorders, a review in the library of the Brazilian Society of Psychoanalysis (SP) allowed observing that disphonia can be a representation of unconscious contents. In this case, the speech therapist must be alert not only to the acoustic production, but also to the meanings of the voice in the patient's history ${ }^{37}$. Another study carried out with 40 patients with vocal alterations ratified that psychogenic disorders may interfere in the quality of the voice ${ }^{38}$ and consequently in communication.

Besides, psychoanalysis can also contribute with the analysis of cases of hearing and stuttering. Studies carried out with deaf adolescents, in the light of psychoanalysis, indicated that family emotional conflicts may be interfering in their hearing quality ${ }^{39}$. Concerning disfluency, a plan of treatment of chronic stuttering carried out with 30 patients in the Institute of Psychoanalysis of Chicago demonstrated that the profile off personality can improve the development of individual plans of treatment ${ }^{40}$.

Literature demonstrated so far that the speech therapeutic practices have an interface with the psychoanalytic theory and are predominantly clinic. However, a psychosocial study was identified. An intervention carried out in a Center of Psychosocial Attention demonstrated contributions from psychoanalysis to the field of Mental Health. The theoretical formulations of Freud and Lacan allowed changes in the act of telling and building stories, as well as in the interaction and communication established between the members of the groups ${ }^{41}$.

\section{CONCLUSION}

This study identified researches which were published in national and international journals and that integrate psychoanalysis to language and hearing sciences. The predominant language was Portuguese and Original Article, the prevalent type of study. It was noticed that language and hearing manifestations do not appear isolatedly. They are influenced directly or may be caused by issues that are inherent to the psychic aspect of the individual.

Psychoanalysis contributes to the analysis and intervention of the cases of hearing, stuttering, voice, writing and, especially, language. Language is the object of study of language. hearing sciences and psychoanalysis, however, the journals of psychology are the ones that most publish researches about psychoanalysis and speech therapy/communication.

As observed in this study, the knowledge about the psychoanalytic theory offers subsidies for speech therapists to identify the origin of the symptoms and define the most adequate strategies of intervention for each case. Thus, an interface between these two areas is necessary, in order to provide a better comprehension and intervention in the communicative alterations.

\section{REFERENCES}

1. Ferraz MGCF. Sujeito psíquico e sujeito linguístico: uma introdução aplicada à fonoaudiologia. Marília: Unesp-Marília-Publicações; 2001.

2. Freud S, Strachey J. The ego and the id. WW Norton \& Company; 1962.

3. Laplanche J, Pontalis JB. Vocabulário da psicanálise. São Paulo: Martins Fontes; 1991.

4. Nascimento EN, Santos FR, Ferreira DMO, Oliveira SA, Silva NN, Riato LA et al. Caracterização das publicações periódicas nacionais integrando fonoaudiologia e psicologia: estudo longitudinal. Distúb. Comun. 2016;28(3):568-80.

5. Mori JS, Machado FP, Cunha MC. Fonoaudiologia e Psicanálise: caracterização dessa interface na formação acadêmica de 
fonoaudiólogos e no discurso de docentes de cursos de Fonoaudiologia. Distúrb. Comun. 2012;24(2):239-47.

6. Bondi L. Understanding feelings: Engaging with unconscious communication and embodied knowledge. Emotion, Space and Society. 2014;(10):44-54.

7. Gil AC. Como elaborar projetos de pesquisa. 4 ed. São Paulo: Editora Atlas SA; 2002.

8. Hochman B, Nahas FX, Oliveira Filho RS, Ferreira LM. Desenhos de pesquisa. Acta Cir. Bras. 2005;20(2):2-9.

9. Vasconcelos SVD, Pessoa ACRG, Farias APDS. Periodicals' profile in speech-language and hearing pathology and neurosciences: study on types and headers of the language area articles, and their visibility. Rev. CEFAC. 2009;11(1):50-8.

10. Ferreira FR. A produção de sentidos sobre a imagem do corpo. Interface- Comunic. Saúde. Educ. 2008;12(26):471-83.

11. Zeddies TJ. More than just words: A hermeneutic view of language in psychoanalysis. Psychoanalytic Psy. 2002;19(1):3-23.

12. Vivona JM. Embracing figures of speech: The transformative potential of spoken language. Psychoanalytic Psy. 2003;20(1):52-66.

13. Pollonio CF, Freire RMDC. O brincar na clínica fonoaudiológica. Distúrb. Comun. 2008;20(2):267-78.

14. Serralha CA. Estudo sobre os elementos de uma interpretação invasiva na abordagem psicanalítica winnicottiana. Psico USF. 2012;17(1):43-51.

15. Foster M. Associação livre de ideias: via régia para o inconsciente-a especificidade do método. J. Psicanal. 2010;43(79):201-16.

16. Freire RMAC. About the object of the SpeechLanguage Clinics. Rev. CEFAC. 2012;14(2):308-12.

17. Cutrim RC. A máscara e os sentidos da fala na linguagem do cotidiano: ressonâncias na psicanálise e na fonoaudiologia. Ide. 2007;30(45):45-51.

18. Rizzuto A. Speech events, language development, and the clinical situation. In. J. Psychoanal. 2002;83(6):1325-43.

19. Mancia M. Dream actors in the theatre of memory: their role in the psychoanalytic process. In. J. Psychoanal. 2003;84(4):945-52.

20. Rizzuto A. Psychoanalysis: the transformation of the subject by the spoken word. Psy Quarterly. 2003;72(2):287-323.
21. Sirois $F$. The role and importance of interpretation in the talking cure. The In. J. Psychoanal. 2012;93(6):1377-402.

22. Connolly A. To speak in tongues: language, diversity and psychoanalysis. J Anal Psychol. 2002;47(3):359-82.

23. Hook D. Nixon's "full-speech": Imaginary and symbolic registers of communication. J Theor Phil Psych. 2013;33(1):32-50.

24. Griffin FL. Clinical conversations between psychoanalysis and imaginative literature. Psychoanalytic Quarterly. 2005;74(2):443-63.

25. Costa CGD, Ribeiro DPDSA, Volpato AL, Abrão JLF. Reflexões psicanalíticas Winnicottianas sobre o sentido do silêncio no settin. Bol. Psicol. 2013;63(138):49-63.

26. Buchholtz M, Spiekermann J, Kächele H. Rhythm and Blues-Amalie's 152nd session: From psychoanalysis to conversation and metaphor analysis-and back again. In. J. Psychoanal. 2015;96(3):877-910.

27. Sanches SB. Busca por representação: a psicanálise e o trabalho de construção. Psicol. Clín. 2014;26(1):165-79.

28. Lombardi R. Mental models and language registers in the psychoanalysis of psychosis: An overview of a thirteen-year analysis. In. J. Psychoanal. 2003;84(4):843-63.

29. Martins F, Costa ACD. Who are they?. Psic., Teor. Pesq. 2003;19(1):91-6.

30. Robbins $M$. The language of schizophrenia and the world of delusion. In. J. Psychoanal. 2002;83(2):383-405.

31. Barros L, Danziato L. Intervenção tardia: reflexões sobre uma intervenção possível no autismo infantil. Reverso. 2010;32(60):43-7.

32. Busch de Ahumada LC, Ahumada JL. Contacting a 19 month-old mute autistic girl: A clinical narrative. In. J. Psychoanal. 2015;96(1):11-38.

33. Moro MP, Souza APRD. Interview with parents in autistic spectrum therapy. Rev. CEFAC. 2012;14(3):574-87.

34. Rocha ACO, Baptista MG, Maia SM, Novaes BC. Atendendo irmãos na clínica fonoaudiológicaalgumas reflexões. Distúrb. Comun. 2013;25(3):452-7.

35. Pereira AS, Keske-Soares M. Patologia de linguagem e escuta fonoaudiológica permeada pela psicanálise. Psico. 2010;41(4):517-24. 
36. Perrotta C, Maia SM. O manejo na terapia fonoaudiológica em um caso de linguagem escrita: o caminho percorrido por Eros para encontrar a princesa adormecida. Distúrb. Comun. 2007;19(3):389-401.

37. Pinheiro MG, Cunha MC. Voz e psiquismo: diálogos entre fonoaudiologia e psicanálise. Distúrb. Comun. 2004;16(1):83-91.

38. Reiter R, Rommel D, Brosch S. Long term outcome of psychogenic voice disorders. Auris Nasus Larynx. 2013;40(5):470-5.

39. Bremm ES, Bisol CA. Sinalizando a adolescência: narrativas de adolescentes surdos. Psicol. Cienc. Prof. 2008;28(2):272-87.

40. Feinberg AY, Griffin BP, Levey M. Psychological aspects of chronic tonic and clonic stuttering: Suggested therapeutic approaches. Am. J.Orthopsychiatr. 2000;70(4):465-73.

41. Zanotti SV, Oliveira AAS, Bastos JA, Silva WVN. Jornal do CAPS: Construção de histórias em Oficinas Terapêuticas. Psico. 2010;41(2):278-84. 